WIELKIE TEMATY KULTURY W LITERATURACH SŁOWIAŃSKICH

Slavica Wratislaviensia CLXXIII • Wrocław 2021 •AUWr No 3986

https://doi.org/10.19195/0137-1150.173.21

Data przesłania artykułu: 16.08 .2019

Data akceptacji artykułu: 17.02.2020

\author{
NATALIIA DASHKO
}

Uniwersytet Celno-Skarbowy, Dniepropietrowsk, Ukraina

\title{
Концепт пам’яті в художньому дискурсі сучасної української новелістики
}

Концепт пам'яті є одним із найбільш уживаних в українському літературному просторі й різнопланово репрезентується у творах сучасних письменників, де він постає як невід'ємна складова художньої картини світу, характеризується семантичною неоднозначністю, асоціативною заглибленістю й множинністю інтерпретацій, утворюючи різноманітні концептуальні поля (зокрема, пам'ять - книга, пам'ять - історія, пам'ять — життя, пам'ять час тощо), що, власне, і переводить поняття „пам'ять” у ранг концепту, а також дозволяє говорити про концептосферу пам'яті ${ }^{1}$. Цим пояснюється інтерес літературознавства до концепту пам'ять, проте його дослідження в сучасній українській малій прозі залишається поза увагою науковців, що зумовлює актуальність нашої розвідки.

Насамперед слід зазначити, що термін „концепт” на сьогодні вивчається в багатьох аспектах (лінгвокультурологічному, когнітивному, лінгвістичному й психолінгвістичному, літературно-культурологічному, філософському та ін.), що зумовлює існування численних визначень цього поняття. Зупинимося на деяких із них. Так, представник лінгвокультурологічного напряму Юрій Степанов розглядає концепт' як „згусток культури у свідомості людини"; як загальний, фундаментальний образ, що відображає ментальну дійсність ${ }^{2}$ і дозволяє простежити мовні й міжкультурні зв'язки концепту, розвиток „колективного несвідомого” в сучасному суспільстві. Таке розуміння концепту зближує його з архетипом ${ }^{3}$.

1 Під концептосферою пам'яті розуміємо сукупність концептів, безпосередньо пов'язаних $з$ концептом пам'ять, що формують різні смислові поля.

2 Ю. Степанов, Константы: словарь русской культуры, Москва 2004, с. 43, https://www. klex.ru/njk [доступ: 12.02.2020].

3 Архетипи в широкому розумінні - наскрізні символічні структури культури, що асоціюють певний тематичний матеріал свідомого та підсвідомого функціонування людських

Slavica Wratislaviensia 173, 2020

(C) for this edition by CNS 
Олена Кубрякова, представниця когнітивного напряму, тлумачить концепт як „термін, який слугує поясненню одиниць ментальних і психологічних ресурсів нашої свідомості й тієї інформаційної структури, що відображає знання й досвід людини"4. Виходячи 3 такого трактування терміна концепт і визначення пам'яті як „когнітивного процесу, що полягає в запам'ятовуванні, збереженні, відновленні й забуванні набутого досвіду"5, можна стверджувати, що в такому разі й сама пам'ять набуває значення концепту. Хоча дослідниця й називає концепт „оперативною змістовою одиницею пам'яті, ментального лексикону, концептуальної системи й мови мозку, усієї картини світу, відображеної в людській психіці”б, однак, це не означає, що пам'ять $\epsilon$ лише певним обсягом інформації, який впорядковується за допомогою концептів, адже пам'ять — це процес психофізичний: характеристика пізнавальної функції психіки, складова пізнавальної діяльності індивіда.

На думку Сергія Аскольдова, який, власне, і започаткував сучасну когнітивну теорію концепту й запропонував психологічний підхід до вивчення цього феномену, підкреслюючи його суб'єктивну природу, художній концепт позначений психологічною складністю, вирізняється художньою асоціативністю, містить невизначеність можливостей, бо є образним, символічним i „замінює нам у процесі думки невизначену багатоманітність предметів одного й того ж роду"7. Детальне дослідження концепту як категорії, що може бути використана при вивченні художніх творів, належить і Валерію Зусману. За його визначенням, літературний концепт — це такий образ, символ чи мотив, який має „вихід” на геополітичні, історичні, етнопсихологічні моменти, що лежать поза художніми творами й відкривають одночасну можливість великої кількості тлумачень під різними кутами зору ${ }^{8}$.

Таким чином, розглянувши деякі підходи до вивчення концепту, вважаємо, що всі вони мають значення для дослідження концепту в художніх твоpax, адже допомагають заглибитися в саме розуміння концепту, розглянути його в різних ракурсах. Проте, ключовою для літературознавчого аналізу, на нашу думку, є когнітивна теорія концепту Аскольдова, бо окреслює всю багатогранність цього поняття. Використання принципів концептуального аналізу дозволило нам шляхом виокремлення в текстах творів ключових слів, пов'язаних із пам'яттю, виявити різні змістові моделі концепту пам'ять

цінностей. Див. Енциклопедія сучасної Украӥни. Архетипи, http://esu.com.ua/search_articles. php?id=44787 [доступ: 14.02.2020].

4 Е. Кубрякова, Краткий словарь когнитивныхх терминов, Москва 1996, с. 44.

5 Психологический словарь. Память, http://psi.webzone.ru/st/075000.htm [доступ: 06.02. 2020].

6 Е. Кубрякова, Краткий словарь когнитивных терминов..., с. 44.

7 С. Аскольдов, Концепт и слово, [в:] Русская словесность. От теории словесности к структуре текста: Антология, ред. В. Нерознак, Москва 1997, с. 269.

8 В. Зусман, Диалог и концепт в литературе. Литература и музика, Нижний Новгород 2001, c. 13.

Slavica Wratislaviensia 173, 2020

(C) for this edition by CNS 
та його опозиції, варіанти інтерпретацій та асоціацій. За об'єкт дослідження було обрано новели Василя Габора, Володимира Назаренка, Андрія Содомори, Сергія Грабаря й Галини Пагутяк, у яких концепт пам'яті представлений найбільш яскраво.

Перш ніж розглянути втілення концепту пам'ять у сучасній українській новелістиці, зауважимо: він широко вживається й у творах інших жанрів. Наприклад, можна назвати роман Enізодична пам'ять Любові Голоти, у якому концепт пам'яті пов'язаний з родовою пам'яттю, що накладається на історичну пам'ять українського буття 60-90 pp. XX ст., поданих крізь призму індивідуальної пам'яті головної героїні ${ }^{9}$; а також повість-притчу Дерево пам'яті Валерія Шевчука, у якій розгорнуто мотив історичної пам'яті українського народу ${ }^{10}$. Досить цікаву інтерпретацію маємо в романі-епопеї Листя землі Володимира Дрозда, де людська пам'ять трактується як „основа світотворення, своєрідна антитеза проминальності”. Будучи нерозривно пов'язаним з образами книги й історії, концепт пам'яті постає як „мірило духовності людини, ï вкоріненості в культурі, код культурних цінностей і форма посмертного інобуття"11.

У творах сучасних українських новелістів переважно простежується осмислення індивідуальної пам'яті людини як найважливішого онтологічного виміру ії буття. Зокрема, у збірці Про що думає людина Габора концепт пам'яті поданий як спогад про фрагмент світу, пропущений крізь призму авторської уяви, набуваючи таким чином значень не лише індивідуальної, але й автобіографічної та епізодичної пам'яті. Це спогади про дитинство, якісь важливі для письменника події (наприклад, Історія про один долар, що змінила його ставлення до грошей), особливих у його житті людей.

Завдяки епізодичній пам'яті Габор довільно поєднує різні часо-просторові відрізки свого життя. Фрагмент за фрагментом, „здалека-здалека, ніби 3 непам'яті, випливають забуті звуки і починають тривожити душу і нагадувати час минулий і людей, яких знав і любив на цьому світі”12. Часто один кадр пам'яті змінює інший (новела Будинок самотньої людини сьогодні): спогади про батьків, про душевнохворого однолітка, про самотню молоду жінку в чорній фаті, що справляє собі весілля в порожній хаті, i „про рідкісний стан спокою, коли не мусиш нікуди поспішати..."13. Спогади напливають спонтанно й нібито не пов'язані між собою, проте часом вибудовуються в ланцюжки подій. Голос матері, що долинає крізь час і кличе вечеряти,

9 Л. Голота, Епізодична пам'ять: Роман, Київ 2007.

10 В. Шевчук, Дерево пам'яті, https://www.ukrlib.com.ua/books/printit.php?tid=2855 [доступ: 12.08.2019].

11 Н. Дашко, Проблемно-стильовий поліфонізм роману-епопеї „Листя землі” Володимира Дрозда, Дніпропетровськ 2010, с. 35-36.

12 В. Габор, Про щзо думає людина: Візії та невигадані історї, Львів 2012, с. 44.

13 В. Неборак, Про щъо думає Василь Габор, „Zbruč” 10.12.2013, https://zbruc.eu/node/16442 [доступ: 5.07.19]. 
витягає з забуття давню історію про новий спортивний костюм вишневого кольору, випадково обляпаний зеленкою, і ті хвилювання, що довелося пережити малому хлопчикові, яким був сам автор.

Часто пам'ять обертається навколо архетипних образів, одним із яких $\epsilon$ образ саду, який концептуалізується. Так, у новелі Про щяо думає людина, йдучи на роботу це монастирський сад за високою цегляною огорожею (мимо якого щодня ходить письменник), шо викликає в пам'яті інший образ саду - сад дитинства, що ріс на берегах за селом. 3 цим садом пов'язаний спогад про родинну трагедію: самогубство його двоюрідного брата, який повісився на старій яблуні. Повертаючись у спогадах до саду дитинства, герой знову переживає ті самі відчуття: „Ти добре пам'ятаєш іiі, ту велику, розлогу яблуню. [...] ІЇ̈ яблука, білосніжні з червоними, немов потрісканими кров'яними прожилками, були великими і соковитими, сік аж бризкав. Але на смак вони були терпко-кислуватими" 14 . Таким чином, образ саду символізує зв'язок між минулим і сучасним, а концепт пам'яті співвідноситься 3 асоціативною пам'яттю, що невипадково, адже всі новели збірки Про щяо думає людина, за словами письменника, написані в стилі вільного слідування пензлю (японського жанру дзуйхіцу), тобто асоціативного письма ${ }^{15}$.

Можна говорити про те, що образ саду в новелі Габора набуває значення місия пам'яті, хоча зазвичай цей термін пов'язують із історичною, колективною пам'яттю, адже концепція місць пам'яті французького історика П'єра Нора ${ }^{16}$, що спирається на історію ментальностей, передбачала вивчення топографічних, символічних, монументальних місць, з якими суспільство пов'язує свої спомини. Проте німецька дослідниця Алейда Ассман у праці Простори спогаду. Форми та трансформащї культурної пам'яті виділила кілька рівнів місиь пам'яті, серед яких і особистісний, що співвідноситься зі спогадами про події життя окремої людини ${ }^{17}$. У контексті новели спогади як локалізоване в часі відтворення образів минулого письменника безпосередньо торкаються його індивідуальної пам'яті й знакових для неї місць. Сад для Габора стає тим місцем, що стимулює пригадування минулих подій, стає образом цього минулого, а отже, — місием пам'яті.

В інтерпретації Габора концепт пам'яті пов'язаний і з іншим архетипним образом - образом будинку (новела Будинок самотньої людини сьогодні). Автор подає детальний опис цього будинку: „Це був якийсь дивний будинок, багато вікон якого було закрито масивними віконницями. Ззовні -

14 В. Габор, Про щчо думає людина..., с. 11.

15 Ibidem, c. 7.

16 П. Нора, Всемирное торжество памяти, „Неприкосновенный запас. Дебаты о политике и культуре” 2005, № 2-3, https://magazines.gorky.media/nz/2005/2/vsemirnoe-torzhestvopamyati.html [доступ: 13.08.2019].

17 А. Ассман, Простори спогаду. Форми та трансформаиії культурної пам'яті, пер. К. Дмитренко, Л. Доронічева та О. Юдіна, Київ 2012, http://shron1.chtyvo.org.ua/Aleida_Assmann/Prostory_spohadu.pdf [доступ: 06.07.2019]. 
триповерховий. А всередині, якщо врахувати підвал, — майже дев'яти"18. Будинок усередині міг би видатися то підземним царством, то загадковим лабіринтом, що має безліч кімнат, дверей, які можна відкрити лише якимось спеціальним ключем. Тільки вже сама пам'ять стає відображенням цього будинку. 3 цього приводу Віктор Неборак зазначає:

Пам'ять - це не впорядкований архів, де будь-коли можна відшукати потрібну інформацію. Габорові його пам’ять нагадує химерний будинок з багатьма кімнатами на кожний рік по кімнаті [...], і багато з тих кімнат виявляються незаповненими. Так стається не тому, що деякі роки були безподієвими, а тому що ті події стерлися з пам'яті ${ }^{19}$.

Таким чином, актуалізується семантична опозиція пам’ять-забуття.

Архетип будинку окреслює етико-естетичні домінанти етнічної свідомості і є найбільш значимим екзистенціалом, пов' язаним із життям головного героя та його пам'яттю, і в новелі Назаренка Дзеркало. На відміну від Габора, Назаренко не подає опису образу будинку, а тільки відзначає факт його знищення й наголошує на внутрішніх станах героя-оповідача, спричинених цією подією: „Спочатку всі мої почуття зводилися до сліпого протесту. [...] Тож коли час сліпого протесту минув [...], з’явився страх. Я здогадався, що й мене можуть зламати, за якимось невідомим мені законом, як будь-яку споруду"20. Тож, образ будинку проєктується на образ людини (невипадкова в такому контексті назва Дзеркало). Головний герой відчуває духовну порожнечу й руйнацію ніби самого себе, що акцентовано в словах: „Руйнуючи матеріальне поза мною, руйнують одночасно духовне в мені"21.

У цьому контексті доречно пригадати працю французького філософа Гастона Башляра Поетика простору, присвячену аналізу сакральних просторів, феномену будинку зокрема, у якій він розглядає простір, як ,інструмент аналізу людської душі”. Дослідник зазначає:

Образ будинку воістину дає принцип психологічної інтеграції, дозволяючи описовій психології, психоаналізу, феноменології об'єднатися в науковий корпус, який ми називаємо топоаналізом. Розглянутий у різних теоретичних планах, образ будинку, здається, представляє топографію нашої глибинної сутності 22 .

Дім для Башляра має грандіозне феноменологічне значення: він місце концентрації внутрішніх процесів людської свідомості й своєрідна точка відліку. Саме такого змісту набуває образ будинку в новелі Дзеркало Назаренка. Будинок стає тим зовнішнім простором, що накладається на внутрішній простір героя, а отже, переживається ним, формує його думки, спогади, пов'язані з індивідуальною пам'яттю.

18 В. Габор, Про щңо думає людина..., с. 43.

19 В. Неборак, Про шзо думає Василь...

20 В. Назаренко, Механічне яйце: Новели, Львів 2014, с. 41.

21 Ibidem, c. 41.

22 Г. Башляр, Избранное: Поэтика пространства, Москва 2004, с. 23, http://yanko.lib.ru/ books/philosoph/bachelard--poetika_prostranstva-2004-81.pdf [доступ: 12.02.2020]. 
У художній інтерпретації Назаренка вибудовується багатокомпонентний асоціативно-семантичний ланцюжок дім-життя-час-людина-пам'ять: був будинок - було справжнє життя; життя без будинку — „життя в деформованому часі”, „постійний рух по кривих площинах, постійна готовність і напруга” 23 . Автор задається питанням: „Що в такім разі і за таких обставин відбувається з пам'яттю?" - і приходить до усвідомлення, що пам’ять теж виявляється здеформованою:

Пам'ять не діє на повну потужність. Це уривки, клапті єдиного пошматованого цілого. Це неспокійний, зосереджений погляд в потужний телескоп (або мікроскоп). Це хвилеве зазирання, це влучний вибір зручної миті підскочити й зазирнути за високий паркан (мисль мислителя), за яким усе твоє минуле $\mathrm{e}^{24}$.

Отже, концепт пам'яті співвідноситься $з$ епізодичною пам'яттю, яка, хоч і деформовано, але зберігає інформацію про цілісні, взаємопов'язані автобіографічні події, надзвичайно важливі для героя-оповідача.

Ставлення героя до будинку грунтується на генетичному мисленні, що бере початок від культу предків. Будинок для нього — це особливий сакральний простір, центр духовного життя, свідченням чого $є$ художня деталь десь там був твій монастир, бо „що може бути святішого від домівки, в якій прожило кілька поколінь?"25. У такому контексті концепт пам'яті безпосередньо пов'язаний із родовою пам'яттю, а сам образ будинку й те місце, де він колись був, набувають значення місиь пам'яті й підтверджують думку Ассман, що „певні місця, що несуть силу спогадів, мають насамперед стійкий і довгий зв'язок із сімейною історією" 26 . Тому для героя життя без будинку стає життям у стані неоголошеної війни проти пам'яті, над якою час не владний: „Ось уже скільки часу минуло, а я й досі не зрозумів, навіщо зруйнували наш будинок. Я і нині, як тоді, — приголомшений, спантеличений, здивований. Це стало моїм звичайним станом"27.

Мотив знищення будинку $є$ ключовим у ряді творів Назаренка, серед яких і новела Повернення. Образ будинку стає символом матеріалізованої $n a м$ 'яті, з утратою якої „людина ніби покинута напризволяще дитина, вилучена з меж ледве засвоєного досвіду спілкування речами" 28 . Автор постійно протиставляє теперішнє життя минулому, до якого немає вороття, але існує повернення в спогадах, і це єдина цінність, що лишилася від домівки: „Все має властивість щезати, зав'язати в болоті, перетворюючись на руїну, на чужину, на дим. Повернення завжди реальне, суперреальне, повернення незнищенне"29. Тим самим стверджується незнищенність людської пам'яті, яка

\footnotetext{
23 В. Назаренко, Механічне яйце..., с. 41.

24 Ibidem, c. 41.

25 Ibidem, c. 42.

26 А. Ассман, Простори спогаду..., с. 320.

27 В. Назаренко, Механічне яйце: Новели..., с. 40.

28 Ibidem, c. 78 .

29 Ibidem, c. 79.
}

Slavica Wratislaviensia 173, 2020

(C) for this edition by CNS 
$\epsilon$ єдиною реальністю, непідвладною часу, адже з руйнацією будинку його історія не припиняється, а продовжує зберігатися в спогадах героя.

Мотив незнищенності пам'яті є наскрізним у новелах збірки Содомори Усміх речей, яку Маркіян Домбровський назвав „книгою про дитинство у спогаді немолодої людини" ${ }^{30}$. Пам'ять постає надійним сховком спогадів про минуле. Ключова роль при цьому відводиться художнім деталям - зоровим і звуковим, які водночас $є$ основними складовими психологічної характеристики героїв, бо акцентують їхні емоційні стани й душевні порухи. У новелі Танець це колористичні речові образи, завдяки яким у пам'яті героїні назавжди закарбувалася історія про втрачене кохання. Невипадково в описі одягу домінує червоний колір — як символ кохання: „Давно б забулась та сумна, $з$ давніх днів, історія, давно б зітерлася з пам'яті, якби не тих кілька штрихів - у кольорах: білий кожушок, червона хустина, така ж довкола стану палахка крайка"31.

Ці речі стають дуже важливими в особистісному, емоційному та меморіальному аспектах. Вони втілюють у собі буття героїні, постають не лише знаком, але й текстом культури, вмістом духовного життя народу, тому сам одяг набуває значення концепту, безпосередньо пов'язаним з концептом пам'яті.

У новелі Забута пісня Содомори пам'ять героя зберігає пісню, почуту колись ним від батька: „Ношу той образ у собі від самого дитинства. I не затирається він, не змінюється"32. Мелодія, що виринає раптово, переводить пам'ять в уяву, щоб „торкнутися когось іще дальшого, без кого й не було б тієї пісні” 33 - далекого предка, який теж співав ту пісню. У новелі Вечір перед Андрісм звукова деталь далекий дівочий голос, що долинає крізь час, набуває лейтмотивного звучання й постає найяскравішим спогадом дитинства героя про свято Андрія: „Скільки-то вже проминуло грудневих Андріїв, а в пам'яті тримається один - найвіддаленіший” ${ }^{4}$. Пам'ять протиставляється забуттю: саме в пам'яті можуть бути зафіксовані й збережені традиції. Автор наголошує на важливості збереження пам'яті для майбутніх поколінь, бо з втратою пам’яті „обривається традиція - те, що передається з рук в руки, 3 уст в уста" 35 .

Пам'ять є основою художньої картини світу й у новелістиці Грабаря. Змістовим центром концепту пам'ять, як правило, виступає лексема спогад: в однойменній новелі (Спогаd) — це спогад апостола Варфоломія про першу зустріч з Учителем і те враження, яке він на нього справив; у новелі Tри кольори спокуси. Червоний — це спогад про пристрасне кохання; у новелі

30 М. Домбровський, У пошуках втраченого усміху, [в:] А. Содомора, Усміх речей: етюди, образки, новели, есеї, Львів 2017, с. 152.

31 А. Содомора, Усміх речей: етюди, образки, новели, есеї, Львів 2017, с. 118.

32 Ibidem, c. 149.

33 Ibidem, c. 149.

34 Ibidem, c. 138.

35 Ibidem, c. 138. 
Гранат - це спогад про перший поцілунок, який стає відліком щастя; а в новелі Свічка - спогад про людей, з якими коли-небудь у своєму житті перетинався головний герой. Цей спогад йому навіяло полум'я свічки: „Я дивився на свічку й згадував тих, кого поруч не було, та про кого я не забував" 36 . Дивлячись на вогник свічки, герой ніби переноситься поза час і простір, що межує з вічністю, а відтак і сама пам'ять співвідноситься з безсмертям й утворює змістову модель пам'ять-вічність.

У новелі Пори року. Зима на перший план письменницьких роздумів Грабаря виходить художнє осмислення світу, що звучить як трагічне передчуття приреченості, Апокаліпсису: „Біла пустеля, легко посріблена. [...] Сонця немає ${ }^{\prime 37}$. Та герой майже й не пам'ятає, як виглядає сонце: „Пам'ятаю трохи, що яскраве: то жовте, то помаранчеве, то червоне. Сонця немає”"38. Герой не знає, як він живе в такому світі - світі безпам'ятства, світі, що перетворився на білу пустелю, де не існує часу (бо зникає пам'ять), де немає жодної живої істоти - i „за всіма логічними розкладами мав би вже давно померти"39, проте він продовжує жити.

Екзистенційне осмислення концепту пам'яті, властиве для літератури останніх десятиліть, простежується й у новелі Пагутяк Bтрата пам'яті. Утрата пам'яті головним героєм, з одного боку — шлях у небуття, а з іншого - порятунок від абсурдного світу, існування людини в якому позначене сірістю, самотністю й порожнечею: „Щойно ви стояли в кінці неймовірно довгої черги невідомо за чим і ваше лице було самотніше і сіріше, ніж звичайно, бо пізня осінь провалила все місто в порожнечу"40. Абсурдність світу підкреслена й художньою деталлю довга черга невідомо за чим. Крім того, світ зображений як трагічний, ворожий, чужий для людини, тому несподівана амнезія героя - єдиний спосіб утекти: „Ви покірно достояли свою чергу і вже коло самого віконця загубилися. Аж так, що забули і сина-ідіота, і рідну дружину, й незнайому жінку, котру при вас тихенько зарізали, і своє ймення. Назву міста, й всі імена та назви, що $€$ на світі” 41 . Знаковим $€$ те, що головний герой не має імені, що підносить його до рівня узагальнення: людина в сучасному світі: „Ви ходите незнайомими вулицями, і ніхто вас не впізнає і не відведе за руку додому"42.

На розвиток мотиву втрати пам'яті спроєктована художня деталь вам вдалося зникнути в темряві, яку можна інтерпретувати неоднозначно: насамперед — це темрява, якою окутаний цей світ, а з іншого боку, герой, забуваючи всіх і все, ніби зникає в темряві власної пам'яті, проте наближається до світла іншого світу:

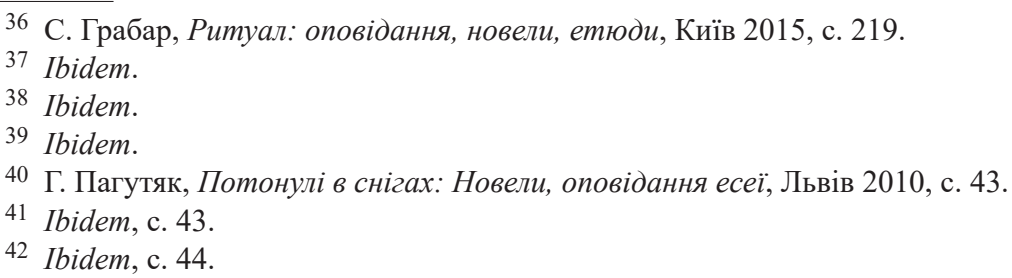

Slavica Wratislaviensia 173, 2020

(C) for this edition by CNS 
Та ось жінка у довгій латаній сорочці підходить, бере вас за руку і веде вниз-внизвниз, у темряву, аж доки попереду не заблисла цяточка світла. [...]. Брудного, зарослого, старого чоловіка нема. $Є$ хлопчик, що сидить на межі й пересипає землю з однієї долоні в іншу ${ }^{43}$.

Таким чином, вибудовується не лише опозиція темрява-світло, а й опозиція двох світів (цей-інший), двох часів (минулий-теперішній), двох образів (старий чоловік-хлопчик), що є складовими опозиції пам'ять - безпам'ятство (амнезія).

Зауважимо, що мотив пам’яті є наскрізним і в есеїстиці Пагутяк. Зокрема в есеї Духи минулого концепт пам'яті пов'язаний з ідеєю платонівського анамнезису — прапам’яті, незмінної присутності минулого в душі людини: „Кожен з нас має минуле, у кожному живе дух його предків, хоче він знати це чи ні" 44 . Використовуючи образ духу минулого, авторка співвідносить його 3 генетичною пам'яттю:

Дух минулого продовжує жити в крові народу, що, може, сам не пам’ятає, чому він такий. Кров, гени - це могутня сила, здатна утримувати сотні, навіть тисячі років майже без змін типи облич і характерів. Люди повторюватимуть ті самі вчинки, тільки житимуть в іншому часі серед інших реалій ${ }^{45}$.

Отже, генетична пам'ять забезпечує зв'язок минулого з сучасністю, що цілком закономірно, адже поняття пам'яті й часу завжди тісно пов'язані, бо сама пам’ять постає втіленням часу.

Таким чином, вибірковий аналіз новел показує, що сучасні українські новелісти по-різному репрезентують концепт пам'яті у творах: як пам'ять індивідуальну, автобіографічну, епізодичну, асоціативну, генетичну — і в кожному конкретному випадку він має свою специфіку художнього зображення. Концепт пам'яті фіксується не лише в знаковій формі (якою є слово пам 'ять зокрема), але реалізується і в асоціаціях та варіантах інтерпретацій, утворюючи різні змістові моделі: пам'ять-спогад, пам'ять-будинок, пам'ять-життя, пам'ять-час, пам'ять-вічність тощо, а також опозиції пам'ять-,непам'ять”, забуття, амнезія. Образи саду (у Габора), будинку (у Назаренка) набувають значення місць пам’яті, що пов'язані з індивідуальною та автобіографічною пам’яттю героїв-оповідачів.

\section{Бібліографія}

Askol'dov S., Koncept i slovo, [v:] Russkâ slovesnost'. Ot teorii slovesnosti $k$ strukture teksta: Antologiâ, red. V. Neroznak, Izdatel'stvo Academia, Moskva 1997.

Assman A., Prostori spogadu. Formi ta transformacï kul'turnoï pam'âtì, per. K. Dmitrenko, L. Doroničeva ta O. Ûdìna, red. O. Ûdìna, Vidavnictvo Nika-Centr, Kiïv 2012, http://shron1. chtyvo.org.ua/Aleida_Assmann/Prostory_spohadu.pdf.
43 Ibidem.
44 Ibidem, c. 154.
45 Ibidem.

Slavica Wratislaviensia 173, 2020

(C) for this edition by CNS 
Bašlâr G., Izbrannoe: Poètika prostranstva, Izdatel'stvo „Rossijskaâ političeskaâ ènciklopediâ”, Moskva 2004, http://yanko.lib.ru/books/philosoph/bachelard--poetika prostranstva-2004-81.pdf.

Daško N., Problemno-stil'ovij polifonizm romanu-epopeï „Listâ zemli” Volodimira Drozda, Vidavnictvo İMA-pres, Dnìpropetrovs'k 2010.

Dombrovs'kij M., U pošukah vtračenogo usmihu, [v:] A. Sodomora, Usmì rečej: etûdi, obrazki, noveli, eseï, Vidavnictvo LA „Pìramìda”, L'vìv 2017.

Enciklopediâ sučasnoï Ukraïni. Arhetipi, http://esu.com.ua/search_articles.php?id=44787.

Gabor V., Pro ŝo dumaê lûdina: Vìiï ta nevigadanì istorï̈, Vidavnictvo LA „Pìramìda”, L'vìv 2012. Golota L., Epizodična pam 'ât': Roman, Vidavnictvo Fakt, Kiïv 2007.

Grabar S., Ritual: opovidannâ, noveli, etûdi, Vidavnictvo Âroslavìv val, Kï̈v 2015.

Kubrâkova E., Kratkij slovar' kognitivnyh terminov, Izdatel'stvo Filol. fak-t MGU, Moskva 1996.

Nazarenko V., Mehanične âjce: Noveli, Vidavnictvo LA „Pìramìda”, L'vìv 2014.

Neborak V., Pro ŝo dumaê Vasil' Gabor, „Zbruč”, 10.12.2013, https://zbruc.eu/node/16442.

Nora P., Vsemirnoe toržestvo pamâti, „Neprikosnovennyj zapas. Debaty o politike i kul'ture” 2005, № 2-3, https://magazines.gorky.media/nz/2005/2/vsemirnoe-torzhestvo-pamyati.html.

Pagutâk G., Potonulì v snigah: Noveli, opovìdannâ eseï, Vidavnictvo LA „Pìramìda”, L'vìv 2010. Psihologičeskij slovar'. Pamât', http://psi.webzone.ru/st/075000.htm.

Ševčuk V., Derevo pam'âtì, https://www.ukrlib.com.ua/books/printit.php?tid=2855.

Sodomora A., Usmì rečej: etûdi, obrazki, noveli, eseï, Vidavnictvo LA „Pìramìda”, L'vìv 2017.

Stepanov Û., Konstanty: slovar' russkoj kul'tury, Izdatel'stvo Akademičeskij proekt Moskva 2004, https://www.klex.ru/njk.

Zusman V., Dialog i koncept v literature. Literatura i muzika, Izdatel'stvo Dekom, Nižnij Novgorod 2001.

\section{The Concept of Memory in the Artistic Discourse of the Contemporary Ukrainian Novel}

\section{Summary}

The article explores the features of the concept of memory functioning in selected contemporary Ukrainian novels. Analyzing the works of Vasyl Gabor, Volodymyr Nazarenko, Andriy Sodomora, Halyna Pahutiak and Serhiy Hrabar the author of the article argues that the concept of memory is presented in Ukrainian fiction in many ways: as individual memory, autobiographical, episodic, associative, genetic - and in each case has its own specifics of artistic depiction. The concept of memory emerges as an integral part of the picture of the world. It is characterized by semantic ambiguity, associative immersion and the plurality of interpretations, forming different semantic models: memory-remembrance, memory-home, memory-life, memory-time, memory-eternity, etc., as well as oppositions memory-"unmemory", oblivion, amnesia. It is noted that the concept of memory is associated with archetypal images such as the concepts of the garden (Gabor) and home (Nazarenko), which acquire the value of memory locations associated with individual and autobiographical memory of story-tellers.

Keywords: novel, concept, memory, individual memory, memory space

Slavica Wratislaviensia 173, 2020

(C) for this edition by CNS 


\section{Концепт памяти в художественном дискурсе современной украинской новеллистики}

Резюме

В статье на материале произведений Василя Габора, Владимира Назаренко, Андрея Содоморы, Галины Пагутяки, Сергея Грабаря исследуются особенности функционирования концепта „память” в современной украинской новеллистике. В результате анализа выявлено, что концепт памяти представлен многоаспектно: как память индивидуальная, автобиографическая, эпизодическая, ассоциативная, генетическая - и в каждом конкретном случае имеет свою специфику художественного воплощения. Данный концепт является неотъемлемой составляющей картины мира, он характеризуется семантической неоднозначностью, ассоциативной глубиной и множественностью интерпретаций, образуя различные смысловые модели: память - воспоминание, память - дом, память - жизнь, память — время, память - вечность, а также оппозиции память — забвение, амнезия. Отмечается, что концепт памяти связан с такими архетипическими образами, как концепты сада (у Габора) и дома (у Назаренко), которые приобретают значение мест памяти, связанных с индивидуальной и автобиографической памятью героев-рассказчиков.

Ключевые слова: новелла, концепт, память, индивидуальная память, место памяти 